\title{
From Traditional to Intelligent Academic Advising: A Systematic Literature Review of e-Academic Advising
}

\author{
Abeer Assiri $^{1}$, Abdullah AL-Malaise AL-Ghamdi ${ }^{2}$, Hani Brdesee ${ }^{3}$ \\ Information Systems Department \\ King Abdulaziz University \\ Jeddah, Saudi Arabia
}

\begin{abstract}
Academic advising plays a crucial role in the achievement of the educational institution purposes. It is an essential element in solving students' academic problems and maximizing their satisfaction and loyalty. Universities around the world have always tried to improve academic advising to personalize the student's experience. In fact, technology has the power to improve the advising process and facilitate its corresponding tasks and this has historically taken different forms. Accordingly, this paper provides an overview of academic advising and the technologies proposed to improve it. The authors present a systematic literature review on research papers that proposed an electronic academic advising system to view the research trends and identify electronic academic advising major challenges. The main contribution of this paper is to survey the different aspects and trends about the electronic systems that have been proposed to serve academic advising. This paper is a part of major research that aims to transfer the traditional academic advising to one based on Artificial Intelligence, via the current phase of academic advising.
\end{abstract}

Keywords-Academic advising system; electronic advising system; higher education; intelligent systems

\section{INTRODUCTION}

Academic advising is a key task in any educational institute that requires a lot of time and expertise. In fact, good advising serves means a high level of student performance, high graduation rate more loyalty, satisfaction level, and more academic success. To help students find the best decision with minimum time and effort the advisor need a copy of student academic record and academic requirement, discuss with the student to understand him and give him advice, or suggestion in a manual way. This traditional style of advising process seems to be a boring and impossible task especially with a large number of students where the advisor cannot meet every student and know his details. Technology utilization in academic advising produces more flexibility and better services.

Automated systems will minimize incorrect advice, minimize the load on academic advisors, solve the issue of the limited number of advisors, and free up more of their time.

This paper is a part of major research that aims to transfer the paper-based academic advising to one based on Artificial Intelligence, via the current phase of academic advising.
This section of the paper will provide an introduction about academic advising to discuss its aims, styles, and short history. The following sections introduce the problem and then analysis available literature using a systematic literature review. It reviews the electronic systems that have been proposed to serve academic advising, shed light on the arising opportunities, with several gaps that require the researchers' attention. It concludes with academic advising systems challenges and future opportunities.

\section{A. Academic Advising}

One main objective of higher education is assisting students to achieve academic success while ensuring that their personal and career needs are fulfilled. Hence, academic advising plays a main role to implement that objective. It is an essential element for a college system to help maximize the students' satisfaction and loyalty, solve their academic problems and guarantee success in their academic and professional goals. It is an indispensable element to achieve the essential goals of higher education institutions [1]. In the O'Banion Model of Academic Advising, this latter is defined as a process in which advisors and students are in an active relationship to understand the student's needs and interests. Ideally, the advisor works as a teacher and guide to improve the student's self-awareness and to achieve his goals [2]. The National Academic Advising Association defined the Academic Advising as a process in which the advisor assists the students to understand and achieve their goals, get information and services, and take reliable decisions suitable with their abilities and academic requirements [3]. In fact, the definitions of academic advising are various, but in general, researchers agree that academic advising refers to the interaction between the students and the representatives of the higher education institutions to achieve student's retention and success.

\section{B. Why Academic Advising?}

According to the Global Community for Academic Advising, National Academic Advising Association (NACADA), the academic advising aims to: educate students about the objectives and the meaning of the institution; inform students about the courses requirements; assist students to understand the courses and programs purposes and enhance students' personal development to achieve academic and career success. Overall, all universities around the world work 
on improving academic advising because it is important and has a key role in students' success, satisfaction, and graduation rate. The advisor guides the student about the academic, personal, and social issues[1]. [2]:

In general, academic advising includes the following task

- Explanation of major, career and life goals.

- Selection of suitable courses and educational plans.

- Clarification of institution requirements.

- Enhancement of the student awareness about learning assistance programs and resources.

- Evaluation of the student performance and goals and reinforcement of student self-direction.

- Advisors often serve as intermediaries between students and instructors in large lecture courses where the enrolled students are counted in hundreds.

Academic advising aims to enhance students' success, raise retention and satisfaction, minimize majors changing, increase the graduation rate, and educate the students about their academic, personal and career goals.

\section{The Traditional Style of Academic Advising}

The academic advising tasks were usually performed in a traditional way using a paper-based form. In the traditional way of advising, both the advisor and advisee sit in a place, where the advisor takes a copy of the student's academic record and requirements, discusses with the student for a better understanding and hence gives him some face to face advice or suggestions. This style of advising has been encountering great difficulty that may disturb the academic advising success and efficiency [4]. In a large university for example and with a huge number of students, communication with each student is an impossible task. Also, the process in the traditional way may be inaccurate where the available information is not always enough, or the advisor experience may not be enough.

- Traditional advising is a time-consuming task that needs a great effort to guide students successfully and efficiently.

- It depends significantly on the advisor's effort and due to the limited time and experience, there is a high possibility of making mistakes. It is important that advisors have good knowledge about academic requirements, educational plans, and rules.

- In some cases, programs are under review and advisors are sometimes not up to date. Such deficiency can result in inaccurate advice [4].

- The advising sessions are limited in time, notably during the highest-demand periods.

- The advising quality is affected by the meeting time length. Advisors usually spend less time with students if they have a high number of students or dash the advising process to minimize the load of the advising meeting. Usually, this happens in the registration periods where many students need to meet the advisor [5].

- The student in the traditional academic advising method spends a long waiting time to meet the advisor and the student available time may clash with the advisor lectures time.

- Incorrect representation of information may cause mistakes in the advising. Advisors need to use multiple files and documents at a time, which makes the advising process boring while they are switching between multiple sources [6].

\section{Technology in Academic Advising}

Technological transformation partly changes the way of student advising delivery. Electronic resources are available and easily accessible in most universities which are one way of 'non-traditional' advising. Technology utilization changes the traditional advising services from direct human interaction to the automated online advising style [5]. In fact, the academic institution uses technology in academic advising to reduce costs, produce more flexibility, accountability, facility, and better streamlined services, which in return increase the graduation rate and the student satisfaction level. Technology contributes in making informed decisions and in providing better services. Despite offering an alternative for the students who are unable to meet the advisor physically, advisors should consider technology as a helping tool to ease the advising process, enhance the advising experience and alleviate workload but they should not regard it as a substitute to human advice [7]. The integration of human and technology will help save time for advisors, enhance the student's experience, satisfaction and facilitate graduation on time [8].

\section{E. Brief History of Using Technology for Academic Advising}

Student advising has historically taken many different forms, all of which were used to assist the students as they proceed toward their goal of degree achievement and to increase their loyalty and satisfaction. Considerable attention has been devoted early to improve the advising task and different universities around the world have recently converted into using technology in order to improve their service level and increase their students' satisfaction using different methods.

Since 1990s Miami University and Georgia State University started using the web to provide information to students, such as lists of open classes and degree requirements, process transactions, class registration, updates of students' addresses and graduate applications [9].

Also, the University of Central Florida, or UCF, is a good example for the university that transformed early to the technology in the advising system. Since the mid-1990's the graduate programs of UCF have used different tools for student's advising. In the beginning, the student was required to write the courses that he has taken in a template paper and the advisor enters this information in a system called Student Academic Support System (SASS). The SASS was used only to store and retrieve the student data to facilitate the advisor's 
tasks. But it was hard to read and not easy to update or change the student's data; and most of the advisors did not prefer to deal with it. In 2007, the university administrators updated SASS to the Degree Audit Reporting System (DARS). The DARS system also was not easy to read and unreliable hence it did not show non-course related requirements. Also, realtime information was not available. DARS system caused confusion and mistakes were being made when certifying students for graduation because the graduation audits format was different from the system. The university IT team worked on improving the system to speed up the advising process and the degree certification process. Between 2011 and 2013 the university decided to use PeopleSoft Advising Tool. The tool was facilitating the work and saved a lot of time in advising and system maintenance [8]. Since Fall 2017, UCF started using Student Success Collaborative system, which is an online tool that is used to connect students to faculty, staff, and campus resources. SSC system provides advisors with predictive analytics technology to help students in decision making. It also helps to track student progress and develop new individual plans [10].

Georgia State University also has great experience in using technology for academic advising. They applied a data-based, problem-solving approach to increase the graduation rates and facilitate student success. In 2012, GSU launched a data analytics system called Graduation and Progression Success (GPS). The system uses previous 10 years student data and grades, to make predictive analytics for how students will perform in the courses, indicate in-risk student and graduation rate. GPS updates student grades and records each night and sends notifications about in-risk students to the advisors. The GPS system allows advisors to identify the obstacles that face students and follow their progress. Also, it has enabled advisers to build advice to the students based on facts, instead of opinions. Currently, this system is available only for the advisor not for the student [11].

Athabasca University of Canada has developed the eAdvisor system since 2003. It was a web-based system used to facilitate program planning and advising process for Information System master student and they reported the success of that experience and were looking to improve it [12].

Also, since 2012 Virginia Commonwealth University (VCU) has started using technology and student data in the advising process to solve problems before they appear, and as a result, in 2015, they reported that student graduation rate increased to 62 percent from 59 percent [13]. In [14] IBM and the U-M Artificial Intelligence Lab reported a Sapphire project. They work to improve a cognitive system for an academic advising. The system is able to understand a student's goals and interest, and responses by conversations.

\section{F. Maintaining the Integrity of the Specifications}

The template is used to format your paper and style the text. All margins, column widths, line spaces, and text fonts are prescribed; please do not alter them. You may note peculiarities. For example, the head margin in this template measures proportionately more than is customary. This measurement and others are deliberate, using specifications that anticipate your paper as one part of the entire proceedings, and not as an independent document. Please do not revise any of the current designations.

\section{OBJECTIVE AND RESEARCH QUESTION}

This paper aims to describe the applied research and implemented technologies to solve Academic Advising issues. This paper summarizes recent papers and classifies them to provide an overview of the proposed electronic advising system.

RQ1: What are the topics covered and the proposed technologies for Academic Advising up to now and what are the purposes?

RQ2: What are the challenges in the academic advising system researches and what is the future research area?

\section{METHOD}

A systematic literature review (SLR) is a systematic process used to collect, interpret, and evaluate all possible research work done by various authors that is related to a specific topic, the domain of interests or questions [3]. This systematic literature review provides meaningful ideas by offering a summary of existing researches about electronic academic advising and its models and challenges.

\section{A. A Information sources}

The search was implemented to gather scientific papers and researches from two main sources:

1) Saudi Digital Library (https://sdl.edu.sa/) that covers different academic databases such as IEEE, Scopus, Wiley, SpringerLink and ScienceDirect and more.

2) Google Scholar (http://scholar.google.com).

\section{B. Search Strategy}

The following strings were used as search keywords in the search process.: 'electronic academic advising', 'academic advising system', 'academic advising and artificial intelligent', 'academic advising intelligent system', and 'academic advising and expert system'.

We performed the search process in the Saudi digital library and google scholar for each keyword, and we collected all related papers. Then we applied the inclusion criteria to select papers.

\section{The Inclusion Criteria}

The process of including papers is summarized in the following points:

- Initially, we bound the search process within (20092019) to analyze up-to-date researches only.

- The search strategy is applied to journals and conferences published between 2009 and 2019.

- It is written in English.

- Studies proposed and implemented an electronic solution for academic advising. 
We collected, summarized papers and classified them to provide an overview of the proposed advising system and the intelligent technique that was used.

We excluded the studies published before 2009, the ones not written in English, the reviewed papers, papers that did not propose an advising model or include a practical electronic system.

\section{EleCtronic ACADEMIC AdVISING SySTEMS (EAAS)}

Electronic Academic Advising systems can be defined as the electronic systems that are used to support the advising process in the advising unit in higher institutes. Multiple technologies have been used to improve EAAS starting from transferring students' records to digital instead of paper forms by using artificial intelligence techniques to support the advising process and decision making.

Based on the literature survey, a significant number of researches have emphasized the need to improve the advising process and the quality of advising in higher education. Moreover, considerable researches and studies proposed to improve the advising experience. Utilizing technologies to facilitate advising and increase retention of students is not a new concept. Since the decade of the 90s advising services on academic institutes has had a dramatic paradigm variation. During that period, institutions introduced computer technology to improve the advising function [16]. There are several academic advising systems and frameworks that have been developed to address the gaps, solve problems and improve institutes' services.

According to our research, the proposed systems can be classified based on the automation level, and we categorized these systems as shown in Fig. 1.



Fig 1. Categories of the Proposed Academic Advising Systems.

\section{A. Simple Advising System (AS)}

We can define AS as the systems that simply represent data in a computerized form, facilitate communication with the advisor, perform simple calculations or simple analysis tasks to reduce the human advisor's responsibility. In these systems, human advisors are needed to plan, give advice or suggestion. Those systems are intended more as support tools than as truly intelligent advisors that can actively guide the students and react to changes.

The drawbacks of these types of systems are: they are unable to generate customized advice, the user is required to provide the system with information to generate results, which increases the probability of entering incorrect information and getting an inaccurate result. Besides, the human advisor is still needed with a high workload level.

Author in [4] represents a simple tool developed using Microsoft Excel and VBA scripts to automate some of the advisor's repetitive tasks. It is designed to facilitate the academic planning process. The advisor enters the student plan and transcript manually into two excel sheets, the tool highlights the taken courses and the ones to-be-taken for next semester. Author in [5] proposes a software designed to help students in the course selection process. The software is developed using Python. The students upload the list of passed courses to know the optimal next courses. Author in [6] proposes a decision support tool used to recommend students and advisors in the course selection process to schedule next semester. Author in [7] is a simple system where the authors propose a web-based model for academic advising. The scope of the model focuses on facilitating the communication between student, advisor, staff, and head of the department. Registered students can use the system to complain, evaluate and suggest. The advisor does the follow-up on the complaints and suggestions. The head of the department follows up the department by receiving KPIs reports. Author in [8] also represents this type of system where authors propose a model for academic advising using fuzzy logic. The system is used to help students in course registration decisions. It is implemented using Java programming language as a mobile application. The student must answer six questions and based on his answers the system responds with the percentage value of recommendation for course registration. The application is designed for the student as a target user and it does not consider the academic requirements or database. It gave limited advising with a high error possibility.

\section{B. Intelligent Academic Advising Systems (IAS)}

An Intelligent Academic Advising is a new trend of Artificial Intelligence that aims to automate the academic advising tasks. Intelligent advising systems are systems that generate customized advice and long-term academic planning using algorithms, resource-intensive, database, and complex queries to generate results. This type of system uses different reasoning strategies to generate the result. Furthermore, it allows students to do self-evaluation, it also guides them and reacts to changes. This type is preferred as it provides better outcomes. It reduces manual information entering, and consequently generates accurate results and reduces the human advisor workload.

Intelligent systems for academic advising have been used in a variety of domains such as: course selection, student data analysis, major or program selection, academic planning, scheduling, performance prediction and they use different electronic technologies. Intelligent advising systems can be classified as single-tasking systems or multi-tasking systems. 
1) Single-tasking intelligent advising systems: According to the survey, most of the current systems are designed to perform a single task such as suggesting a course or a major for the students based on the data and knowledgebase. Author in [21] represented JESS rule engine expert system that provides responses to students' queries about academic plan and the program progress. The system data is extracted from the university student database. It recognizes which courses have been taken and which are expected for the next semester. Author in [22] represents an intelligent single-task system designed to be a virtual assistant for the new-comer student to reply to their questions about the university. It is designed using a rule-based system and implemented using CLIPSJNI and JAVA. Author in [23] represents an intelligent dialog system used to advise students (freshman, sophomore, junior or senior) to suitable courses. The system uses natural language processing and an expert system. It is programmed in Artificial Intelligence Markup Language (AIML) and Python. Authors in [24] proposed an intelligent system that predicts student performance using data mining techniques (Decision Trees and Naïve Bayesian Classifiers). The proposed model predicts the student's status to help advisors recognize in-risk and near-risk students.

Author in [7] presented an intelligent course advisory designed using rule-based and case-based reasoning techniques. The system recommends courses to the students based on the students' academic records. The proposed system was implemented in the Computer and Information Sciences Department of Covenant University.

Author in [25] also represents an intelligent system used for course selection. The proposed expert system recommends postgraduate Computer Science College students at King Abdul-Aziz University (KAU) to enroll in suitable courses. The proposed system considers courses prerequisites, department's requirements, and thesis field to generate a semester plan without referring to the advisors. Author in [26] proposed a model of intelligent advising system using a multilayer neural network. The proposed model is used to advise a student to join a suitable college based on his interests. Students answer certain questions to find out a suitable branch or college selection. Author in [27] presented a neuro-fuzzy logic system for Malaysian universities. It is used to advise the student to select a suitable major. It is a webbased system, implemented by using Microsoft Visual Studio 2017 incorporated with SQL 2014. Author in [28] proposed an early warning tool that uses learning analytics to categorize the student's performance based on his database. The target system user is the academic advisor. The system is used to help advisors in the advising process, notice the students' setbacks and in turn facilitate advisors' conversations with the students about their performance and effort. Author in [29] proposed a system of an automated advisor to help students in major selection using the Case-Based Reasoning System. This system gives advice to the student about the best major for him after comparing his case with the previous ones. The comparison identifies the similarities of the course contents which are used in calculating the achievements and the major matching. Based on the list of recommendation, the student can decide the best major for him. It was proven to be quite effective when enough historical cases are provided in its knowledge base.

Author in [30] proposed a web-based advising system designed using a data mining algorithm (K-means). The system categorizes students into groups based on their characteristics and behavior and gives them advice about the best courses based on their similarities. Authors in reference [31] proposed an advising system that is used to help students in the course selection task. The system is designed using data mining technique (association rule mining). It suggests courses that meet students' needs to improve their academic performance. The system uses real data from Computer Information Technology College at Jordan University. Authors in [32] proposed XML user-based Collaborative Filtering (CF) system. The system is used to advise students to take courses that were successfully passed by other students with similar interests and level of the performance. The system was implemented and evaluated by real students from Texas at Arlington-USA and Khalifa University-UAE. Author in [33] proposed a decision support system called IDiSCS. It is used for individual course scheduling according to students' goals and interests. Optimization algorithms were used to perform a pro-active analysis to suggest a balanced schedule that satisfies both student preferences and academic constraints. The system is validated using real-world examples. Author in [34] proposed a web-based course recommendation system utilizing multi-agent technologies with content-based filtering, collaborative filtering, and a knowledge-based approach.

Author in [35] proposed a new decision support system founded on case-based reasoning and rule-based reasoning. The system is used to help students in the major selection process considering student academic and personal interest. It is also used to generate three major recommendations strong, mild, and weak.

2) Multi-tasking intelligent advising systems: Likewise, there are a few systems designed to address the academic advising unit multiple issues. Of course, the multi-tasking systems are the optimal approaches of advising solutions; and academic institutions prefer them. Such systems minimize incorrect advice, reduce the load on academic advisors, solve the issue of the limited number of advisors, and free up more of their time for other tasks, such as managing special personal cases [10].

Author in [36] presents a multi-tasking intelligent natural language advising system in the University of Florida's Department of Electrical and Computer Engineering. The researcher developed a well-defined, conversational question answering application, like other commercial systems such as SIRI with Apple. The system provided students with an online automated advising system that is close to the traditional human interaction. It has a conversational agent that is utilized as a user interface and contains data collection modules, data management, and knowledge base. Author in [5] proposed an intelligent system using a semantic web expert system that 
provides the dynamic future required in the academic advising field. The generated system succeeds in providing the required services and in attaining a high acceptance level. The system has mixed an intelligent service (course advising, graduation status information, oral exam qualifications) and a nonintelligent service (email communication).

Author in [9] introduced a learning analytics system that is used to predict the student's risk and to compile his plan based on his history. It is implemented as a web application using Python and Meteor frameworks.

Author in [10] represents an academic advising system using Data Mining algorithms to understand students' performance levels, students' registrations, and module marks. Also, it facilitates decision making about the next courses' enrolment process. Author in [11] proposed an intelligent automated advising system using the bot framework. The system is implemented using both agent and object-oriented approaches. It supports students and assists the advising process by making fast and easy access to useful information and helps in considering some academic issues that usually take considerable time. The system splits into database as a backend, AdvisorBot as a front agent, Knowledge Base, and Cognitive module. The designed chatbot is able to answer students' questions about academic performance, courses, and future career. Author in [12] also proposed a chatbot for Hong Kong Open University students. It provides the student with courses information, it collects students' opinions, and provides a recommendation. The chatbot is applied on the telegram as a communication medium. The designed chatbot provides a description of the courses by suggesting the course website or booklet to the student.

Authors in [13] proposed an early warning system that is used to identify at-risk students and notify advisors about them to prevent student dropout. The system also accurately predicts student dropout risk and delivers it with student performance information and some background to the advisor on a weekly basis. In this way, the system increases the meeting quality between student and advisor. The system is implemented by using machine learning techniques (Logistic Model (LM), the Additive Logistic Model (ALM), the Support Vector Machines (SVM) model, and the Random Forest (RF) Algorithm.).

Author in [14] represented two educational expert systems used to recommend the courses and scholarships based on the student's eligibility. The scholarship recommendation system is the first proposed system of this type. Both expert systems are implemented and tested by the Oracle Policy Automation (OPA) software.

Author in [15] proposed a new system called Tarot. The system consists of a planning engine designed for course advising. The system is able to develop a long-term academic plan, it also handles a variety of questions about some present and future matters such as: maximum course load, student GBA, the best time to take a certain course and the minimum number of teachers needed to cover possible registered courses. The system was implemented using Prolog with complex constraints and rules. The system lacks proper user interfaces where the user queries must be a command line.

\section{DISCUSSION}

Referencing this literature review, the proposed academic advising systems can be classified upon the automation level and technologies used into two main categories: Simple and Intelligent. Intelligent systems can be classified based on their purposes or tasks to multi-tasking systems and single-tasking systems. We can summarize the academic advising tasks that electronic systems try to address as: the process of selecting suitable courses, major or program selection, communication between student and advisors, the barriers of academic planning and scheduling, the tasks of student academic performance follow-up, students' retentions, providing students with useful information, responding to their queries and frequently asked questions. Table I summarizes the advising tasks and papers that proposed electronic solutions.

Table II shows all the papers included in our research. It summarized the papers' objectives, the technologies used in the proposed system weaknesses and advantages. Table II answers our research question 1 in detail. We can notice that most of the proposed system is designed for course selection and course recommendation (14 out of 30 articles). Most of the proposed systems are single-task systems, only 9 out of 30 articles proposed a multi-tasking system. Data mining techniques and decision support systems are the most used techniques. Only two articles proposed chatbots techniques for advising. Most authors in literature agreed that the technologies are essential in academic advising. They recommended the electronic advising system as a support tool. They indicated artificial intelligence and expert systems as the best tools to facilitate advisor tasks and to increase quality but advising robots cannot come soon to fully replace human advisors [16].

TABLE I. ClassifiCATION OF PROPOSED PAPER BASED ON THE ADDRESSED CHALLENGES

\begin{tabular}{|l|l|}
\hline Addressed Challenges & Ref. of Proposed Papers \\
\hline Course selection & $\begin{array}{l}17,18,20,7,21,23,25,30, \\
31,32,34,5,42,43\end{array}$ \\
\hline Major or program selection & $26,27,29,35$ \\
\hline $\begin{array}{l}\text { Communication, answering student queries } \\
\text { and frequently asked questions }\end{array}$ & $19,21,22,5,36,39,40,43$ \\
\hline Academic planning and scheduling & $6,33,37,38,43$ \\
\hline Academic performance follow-up & $24,28,37,41,38$ \\
\hline Scholarship recommendation & 42 \\
\hline
\end{tabular}


TABLE II. SUMMARY OF EAS PAPERS

\begin{tabular}{|c|c|c|c|c|c|}
\hline $\begin{array}{l}\text { Technologies } \\
\text { used }\end{array}$ & Research objective & Ref. & Weaknesses: & Advantages: & $\begin{array}{l}\text { System } \\
\text { category }\end{array}$ \\
\hline Microsoft excel & Academic planning & {$[4]$} & $\begin{array}{l}\text { The proposed tool is not integrated with the } \\
\text { database where advisors must manipulate } \\
\text { the student's plan, transcript, and results } \\
\text { manually. } \\
\text { Lack of theoretical foundation. }\end{array}$ & $\begin{array}{l}\text { The tool is used to help in the strategic } \\
\text { decisions process to decide which courses } \\
\text { should be provided for the following } \\
\text { semester. } \\
\text { The tool facilitates the advisors' work on the } \\
\text { course selection process. }\end{array}$ & Simple \\
\hline Python Software & Course selection & {$[5]$} & $\begin{array}{l}\text { Failed to report some limitations and future } \\
\text { motivations. } \\
\text { The software generates the following } \\
\text { semester courses without considering the } \\
\text { student's performance history. } \\
\text { The tool provides poor user interface. }\end{array}$ & $\begin{array}{l}\text { The proposed tool can help the advisor in } \\
\text { the course registration process. }\end{array}$ & \\
\hline $\begin{array}{l}\text { Decision support } \\
\text { system }\end{array}$ & Course selection & {$[6]$} & $\begin{array}{l}\text { No automated decisions nor } \\
\text { recommendations for the advising process } \\
\text { are provided. }\end{array}$ & $\begin{array}{l}\text { The tool shows the students' data on a page } \\
\text { so that it could support a face to face } \\
\text { meeting. }\end{array}$ & \\
\hline $\begin{array}{l}\text { Web-based } \\
\text { system }\end{array}$ & $\begin{array}{l}\text { Complaint, evaluation, and } \\
\text { suggestion in any subject }\end{array}$ & [7] & $\begin{array}{l}\text { The proposed system is limited for } \\
\text { complaint, evaluation, and suggestion } \\
\text { processes. } \\
\text { The model is not integrated with the } \\
\text { university system. }\end{array}$ & $\begin{array}{l}\text { It helps students to evaluate, suggest and } \\
\text { complain with no need of a physical } \\
\text { attendance. }\end{array}$ & \\
\hline $\begin{array}{l}\text { Fuzzy logic expert } \\
\text { system }\end{array}$ & Course selection & [8] & $\begin{array}{l}\text { The tool generates the recommendation to } \\
\text { the suitable course without considering the } \\
\text { student's record and academic requirement. } \\
\text { Lack of evaluation and validation. }\end{array}$ & $\begin{array}{l}\text { The proposed tool is implemented via a } \\
\text { mobile application. } \\
\text { The tool is able to recommend the course } \\
\text { suitability to the student based on logical } \\
\text { criteria. }\end{array}$ & \\
\hline $\begin{array}{l}\text { Case-based } \\
\text { reasoning \&rule- } \\
\text { based reasoning }\end{array}$ & Course selection & [17] & $\begin{array}{l}\text { The system is unable to recommend } \\
\text { complex cases. } \\
\text { Lack of documentation for both student and } \\
\text { advisor reports. } \\
\text { Recommendations are generated based on } \\
\text { students' records only. }\end{array}$ & $\begin{array}{l}\text { The proposed system uses rule-based } \\
\text { reasoning and CBR to recommend courses } \\
\text { to students accurately. }\end{array}$ & \multirow{5}{*}{$\begin{array}{l}\text { Single- } \\
\text { intelligen } \\
t \text { system }\end{array}$} \\
\hline Jess rule engine & $\begin{array}{l}\text { Response to student course } \\
\text { queries }\end{array}$ & {$[18]$} & $\begin{array}{l}\text { Lack of evaluation description. } \\
\text { The system does not consider the students' } \\
\text { GPA and interests. }\end{array}$ & $\begin{array}{l}\text { The system responses to a set of students' } \\
\text { queries. } \\
\text { System rules are implemented in an XML } \\
\text { file which makes the system extensible and } \\
\text { scalable. }\end{array}$ & \\
\hline $\begin{array}{l}\text { Rule-based } \\
\text { system }\end{array}$ & $\begin{array}{l}\text { Newcomer virtual } \\
\text { assistance }\end{array}$ & [19] & $\begin{array}{l}\text { The tool is limited to freshmen only. } \\
\text { The proposed system is unintegrated with } \\
\text { the university system. }\end{array}$ & $\begin{array}{l}\text { The tool provides accurate information to } \\
\text { new-comer students. }\end{array}$ & \\
\hline $\begin{array}{l}\text { Natural language } \\
\text { processing \& } \\
\text { expert system }\end{array}$ & Course selection & {$[20]$} & $\begin{array}{l}\text { The system requires the student's transcript } \\
\text { manually. } \\
\text { The system provided recommendations by } \\
\text { responding to yes and no questions only. } \\
\text { This is an off-line system and it is not } \\
\text { integrated with databases. }\end{array}$ & $\begin{array}{l}\text { The system gives a proposed schedule to the } \\
\text { student which may help in setting an active } \\
\text { session with advisors. }\end{array}$ & \\
\hline $\begin{array}{l}\text { Data mining } \\
\text { techniques }\end{array}$ & $\begin{array}{l}\text { Student performance } \\
\text { follow-up }\end{array}$ & {$[21]$} & $\begin{array}{l}\text { The proposed model is designed with a } \\
\text { minor students' dataset. } \\
\text { The tool is unable to send early } \\
\text { notifications. }\end{array}$ & $\begin{array}{l}\text { The proposed system identifies the factors } \\
\text { that could affect the student's performance. } \\
\text { It can predict at risk students accurately. }\end{array}$ & \\
\hline
\end{tabular}




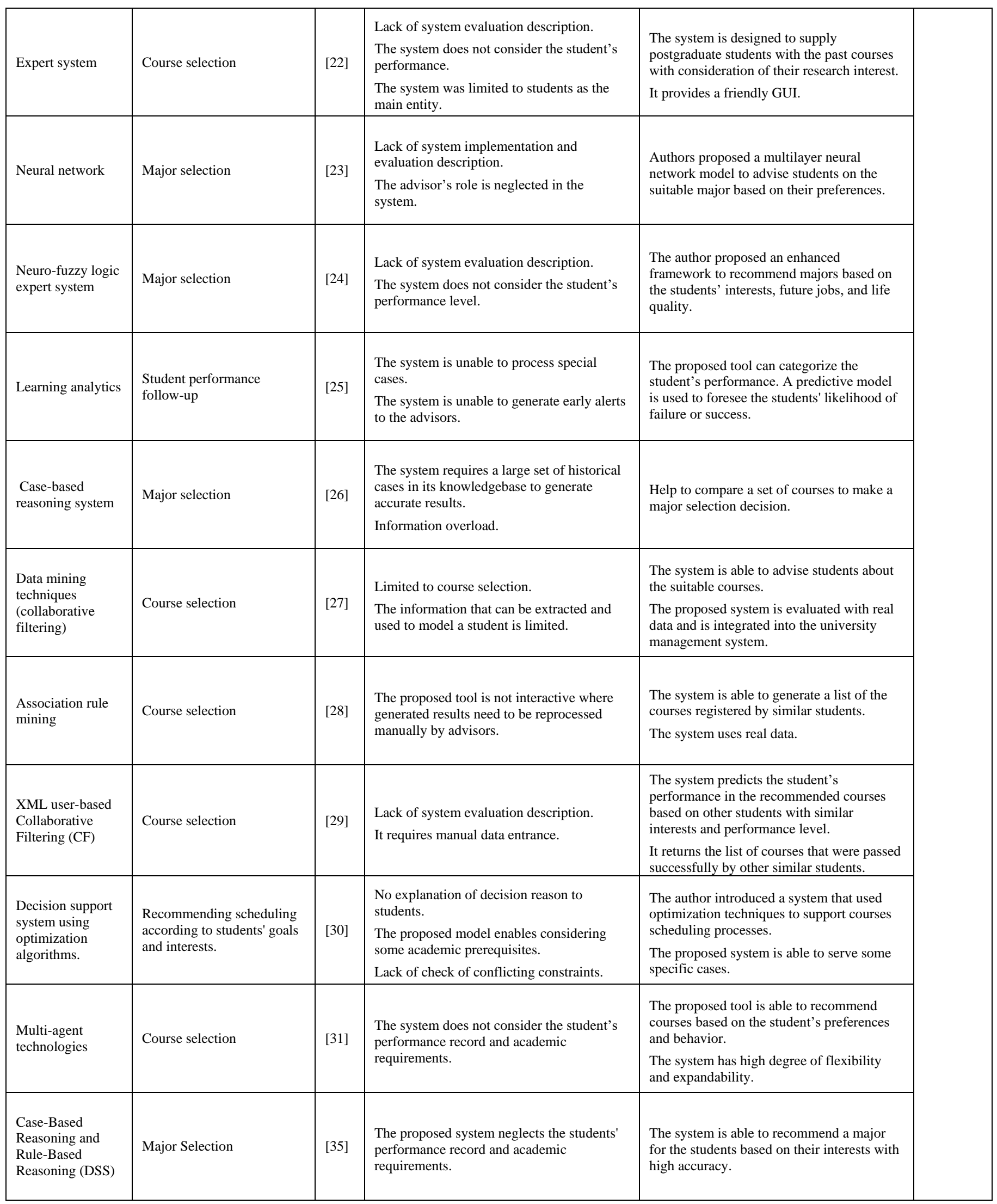




\begin{tabular}{|c|c|c|c|c|c|}
\hline $\begin{array}{l}\text { Natural language } \\
\text { processing }\end{array}$ & Students dialog system & [36] & $\begin{array}{l}\text { The system performance was limited as it } \\
\text { was not integrated with the student's } \\
\text { academic record. } \\
\text { The model generates an error if the user uses } \\
\text { incomplete expressions. } \\
\text { The system neglects the communication } \\
\text { with a human advisor. }\end{array}$ & $\begin{array}{l}\text { The system represents the first } \\
\text { conversational based academic advising } \\
\text { system. It is an expert-based natural } \\
\text { language academic advising system that } \\
\text { provides about } 29 \text { services, a user can } \\
\text { search through using NL. }\end{array}$ & \multirow{9}{*}{$\begin{array}{l}\text { Multi- } \\
\text { intelligen } \\
\text { t system }\end{array}$} \\
\hline $\begin{array}{l}\text { Semantic web } \\
\text { expert system }\end{array}$ & $\begin{array}{l}\text { Course selection - } \\
\text { graduation information - } \\
\text { oral exam qualification- } \\
\text { email }\end{array}$ & [5] & $\begin{array}{l}\text { System is designed to serve clear path } \\
\text { students only; it cannot give advice to } \\
\text { others. } \\
\text { The advisors need to enter the students' } \\
\text { transcripts manually. }\end{array}$ & $\begin{array}{l}\text { The system provides enough accurate advice } \\
\text { and it has a high level of user acceptance. }\end{array}$ & \\
\hline Learning analytics & $\begin{array}{l}\text { Student performance } \\
\text { follow-up, academic } \\
\text { planning }\end{array}$ & [37] & $\begin{array}{l}\text { The study sample size is small. } \\
\text { The tool is unable to send notifications to } \\
\text { advisors. } \\
\text { It cannot generate a long-term plan. }\end{array}$ & $\begin{array}{l}\text { The proposed tool enables advisors to } \\
\text { evaluate the students' performance including } \\
\text { difficult cases. } \\
\text { The tool recommends a plan for the next } \\
\text { semester. }\end{array}$ & \\
\hline $\begin{array}{l}\text { Data mining } \\
\text { techniques }\end{array}$ & $\begin{array}{l}\text { Academic planning, } \\
\text { performance follow-up, } \\
\text { advising session } \\
\text { appointment }\end{array}$ & [38] & $\begin{array}{l}\text { Lack of implementation details description. } \\
\text { The proposed model does not consider the } \\
\text { students' interests and goals. }\end{array}$ & $\begin{array}{l}\text { The proposed system enables advisors to } \\
\text { monitor the students' progress. } \\
\text { The proposed data model can classify } \\
\text { students according to academic standing. } \\
\text { It facilitates the planning and reasonable } \\
\text { actions. }\end{array}$ & \\
\hline Chatbot & $\begin{array}{l}\text { Providing students with } \\
\text { valuable information. }\end{array}$ & [39] & $\begin{array}{l}\text { The paper focused on how to design and } \\
\text { implement the chatbot more than on the } \\
\text { academic advising needs. } \\
\text { The role of the department head was } \\
\text { neglected in the system. } \\
\text { Lack of system evaluation and validation. }\end{array}$ & $\begin{array}{l}\text { The system answers query even if } \\
\text { incomplete or with limited expressions by } \\
\text { intent defined using AIML. }\end{array}$ & \\
\hline Chatbot & $\begin{array}{l}\text { Providing course } \\
\text { information- collecting } \\
\text { students' opinions and } \\
\text { recommendations. }\end{array}$ & [40] & $\begin{array}{l}\text { The system does not advise the user about } \\
\text { the courses according to their options and } \\
\text { constraints. } \\
\text { The system requires more analysis and } \\
\text { recommendation functions. }\end{array}$ & $\begin{array}{l}\text { The chatbot system has an } 80 \% \text { accuracy } \\
\text { and acceptable performance level. } \\
\text { It uses an intent detection to understand the } \\
\text { user need from the input natural language. }\end{array}$ & \\
\hline $\begin{array}{l}\text { Machine learning } \\
\text { techniques }\end{array}$ & $\begin{array}{l}\text { Student performance } \\
\text { follow-up }\end{array}$ & [41] & $\begin{array}{l}\text { The system is unable to provide the reasons } \\
\text { of low performance and dropout reports. } \\
\text { Students are not provided with instructions. }\end{array}$ & $\begin{array}{l}\text { The system is able to notify the advisors } \\
\text { about students' risks and predicts students' } \\
\text { dropout then delivers a report with the } \\
\text { students' performance information to the } \\
\text { advisor on a weekly basis. }\end{array}$ & \\
\hline $\begin{array}{l}\text { Rule-based Expert } \\
\text { system }\end{array}$ & $\begin{array}{l}\text { Course selection and } \\
\text { scholarships. }\end{array}$ & [42] & $\begin{array}{l}\text { Lack of system evaluation description. } \\
\text { The scholarship system did not function. }\end{array}$ & $\begin{array}{l}\text { It proposed the first expert system for } \\
\text { scholarship recommender. } \\
\text { The system is able to recommend courses to } \\
\text { students based on the student's } \\
\text { specialization, prerequisite courses, GPA, } \\
\text { and the current semester open courses. }\end{array}$ & \\
\hline $\begin{array}{l}\text { Constraints and } \\
\text { rules in Prolog } \\
\text { programming } \\
\text { language. }\end{array}$ & $\begin{array}{l}\text { Long-term course } \\
\text { schedules, answering } \\
\text { present and future queries. }\end{array}$ & [43] & $\begin{array}{l}\text { User interface is not appropriately } \\
\text { provided. } \\
\text { The system is time-consuming when it } \\
\text { performs some complex operations. }\end{array}$ & $\begin{array}{l}\text { The system is able to develop the student's } \\
\text { academic plan and courses' schedule even } \\
\text { for complex scenarios. } \\
\text { TAROT system can answer staff, advisor, } \\
\text { and student queries. } \\
\text { TAROT system can support strategic } \\
\text { decision. }\end{array}$ & \\
\hline
\end{tabular}


Many challenges have been observed in the proposed electronic advising systems. We summarized the most critical challenges in electronic academic advising systems as following:

- How to treat special-case students individually because not all students can be treated in the same way.

- How to produce a flexible, accurate advising system that serves multiple advising purposes with ease of use and minimum complexity and information overload.

- The necessity of a holistic approach to include all advising factors like student competency, interests, and goals.

- Minimizing poor results due to the need for human judgment factors or wrong input data.

- Regular updates are essential to assure the accuracy of advice and messages generated by the system.

- Increase in the validity and clarity of rules and guidelines.

- The advising systems should be of high speed to respond quickly, give advice and alerts in a timely manner.

Most of the surveyed literature indicated the importance of embedded electronic advising systems or tools as a part of a well-designed system to increase its efficiency and effectiveness. The system is unlikely to benefit students if it is poorly designed or poorly integrated into the university systems. It is clear that universities and scientific researchers need to work seriously and give more consideration to fill the gaps in the academic advising systems research and to improve it in a way that allows advising to achieve its purposes and goals. In fact, most of the authors agreed that the electronic academic advising domain is rapidly growing and that it is an active area for researches that will continue improving and contributing with valuable works to develop effective advising systems that serve both students and educational institutions [9], [44]. Fig. 2 shows the distribution of researches over the publication years.

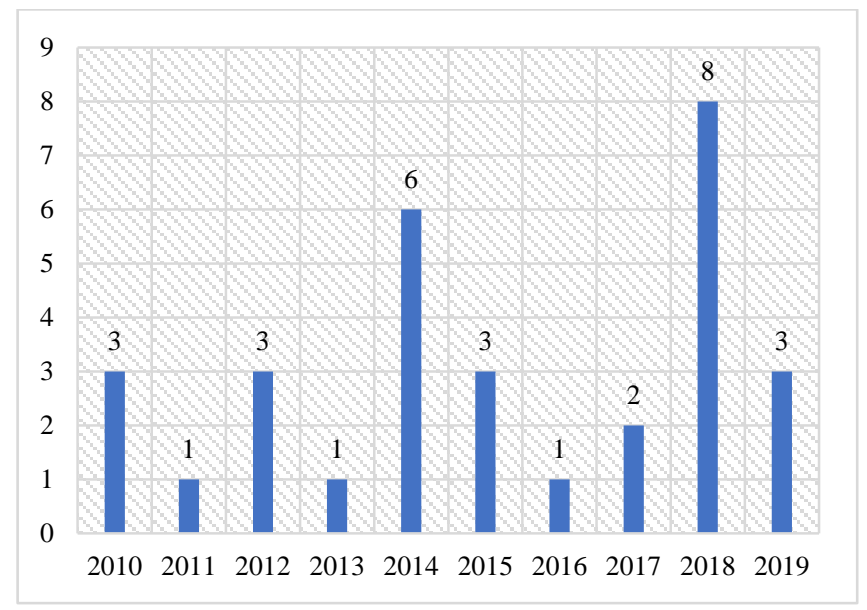

Fig 2. Research Papers Classification over Publication Year.

\section{FUTURE WORK}

For future works, the authors recommend artificial intelligence techniques and expert systems to maximize effectiveness and efficiency. Very few studies in the literature proposed systems related to scholarship recommendation, exploring students' life and interests, career goals, and parodically alerts advisors and students. Also, they indicated the importance of using the multi-tasks system that works as a unified system more than as separated supporting tools. It would be interesting to take advantage of Artificial Intelligent research to introduce innovative academic advising systems in these areas. Implementation of the electronic advising systems must consider integrating the advising system in a welldesigned system (the main university system) and build it based on students' databases. Many parameters must be considered in order to create an efficient advising system, such as effectiveness, maintainability, usability, and portability.

\section{CONCLUSION}

Academic advising is a very important unit in higher education institutions. It plays a great role in students' and institutions' success. Technology has the power to improve this educational field, and many studies have been conducted to improve academic advising applying technology. We conducted this SLR to review the recently proposed electronic systems in the domain. The paper contributes to foster motivation for further research to create reliable and resilient electronic advising systems based on Artificial Intelligence techniques. The analysis of selected proposed systems detected the technologies used by the research communities in this field and its purposes. Along with the arising opportunities, we shed light on several drawbacks and challenges that require the universities and researchers to make extra effort and it foster motivation for further research to create reliable and resilient electronic advising systems.

\section{REFERENCES}

[1] A. David, W. Edwa, and Crockett, 'Academic Advising for Student Success \& Retention: Participant Book', U S A Group Noel-Levitz, Iowa (1997), 1997, p. 255 pages.

[2] N. G. Virginia, R. H. Wesley, and T. J. Grites, Academic Advising: A Comprehensive Handbook, 2nd ed. John Wiley \& Sons, 2011.

[3] J. Burton and K. Wellington, 'The O'Banion Model of Academic Advising: An Integrative Approach', NACADA Journal, vol. 18, no. 2, pp. 13-20, Sep. 1998, doi: 10.12930/0271-9517-18.2.13.

[4] E. I. Nwelih, 'Framework for a Web-Based Spatial Decision Support System for Academic Advising', 2013.

[5] L. K. Henderson, 'AdviseMe: An Intelligent Web-Based Application for Academic Advising', 2015, doi: 10.14569/IJACSA.2015.060831.

[6] M. Al-Nory, 'Simple Decision Support Tool for university academic advising', 2012 International Symposium on Information Technologies in Medicine and Education, Information Technology in Medicine and Education (ITME), 2012 International Symposium on, p. 53, 2012, doi: 10.1109/ITiME.2012.6291245.

[7] O. Daramola, O. Emebo, I. Afolabi, and C. Ayo, 'Implementation of an Intelligent Course Advisory Expert System', International Journal of Advanced Research in Artificial Intelligence, vol. 3, no. 5, 2014, doi: 10.14569/IJARAI.2014.030502.

[8] T. Gaines, 'Technology and Academic Advising: Student Usage and Preferences', NACADA Journal, vol. 34, no. 1, p. 43, Jan. 2014.

[9] 'Applying Technology to Academic Advising" by Munkwitz-Smith, Jeffrey von - College and University, Vol. 81, Issue 1, Summer 2005 Online Research Library: Questia Reader'. 
https://www.questia.com/read/1P3-1070950051/applying-technology-toacademic-advising (accessed Nov. 09, 2019).

[10] 'Student Success Collaborative at UCF - UCF Faculty Center for Teaching and Learning', http://www.fctl.ucf.edu/FacultySuccess/PromotingStudentSuccess/ssc.p hp (accessed Mar. 12, 2019).

[11] M. Kurzweil and D. D. Wu, 'Building a Pathway to Student Success at Georgia State University', Ithaka S+R, New York, Aug. 2015. doi: $10.18665 /$ sr.221053.

[12] F. Lin, S. L. D. Wen, F. Z. Kinshuk, and R. McGreal, 'e-Advisor: A Multi-agent System for Academic Advising', 2007.

[13] 'Using data-driven advising, colleges find more students eligible to graduate'. https://www.insidehighered.com/news/2015/12/09/usingdata-driven-advising-colleges-find-more-students-eligible-graduate (accessed Apr. 17, 2019).

[14] 'U-M, IBM partner on advanced conversational computing system', University of Michigan News, Jan. 14, 2016. https://news.umich.edu/um-ibm-partner-on-advanced-conversational-computing-system/ (accessed Dec. 30, 2019).

[15] C. Okoli and K. Schabram, 'A Guide to Conducting a Systematic Literature Review of Information Systems Research', 2010, doi: 10.2139/ssrn.1954824.

[16] J. Kulls, 'An Alternative Approach for Advising Online Students', NASPA-FL - Florida Atlantic University, p. 15, May 2017.

[17] M. S. Laghari, 'EE Course Planning Software System', JSW, vol. 13, pp. 219-231, 2018, doi: 10.17706/jsw.13.4.219-231.

[18] T. Feghali, I. Zbib, and S. Hallal, 'A Web-based Decision Support Tool for Academic Advising', Journal of Educational Technology \& Society, vol. 14, no. 1, pp. 82-94, Jan. 2011.

[19] E. Afify and M. Nasr, 'A Proposed Model for a Web-Based Academic Advising System', vol. 09, no. 02, p. 17, 2017.

[20] W. M. Aly, K. A. Eskaf, and A. S. Selim, 'Fuzzy mobile expert system for academic advising', in 2017 IEEE 30th Canadian Conference on Electrical and Computer Engineering (CCECE), Apr. 2017, pp. 1-5, doi: 10.1109/CCECE.2017.7946846.

[21] A. N. Nambiar and A. K. Dutta, 'Expert system for student advising using JESS', in 2010 International Conference on Educational and Information Technology, Sep. 2010, vol. 1, pp. V1-312-V1-315, doi: 10.1109/ICEIT.2010.5607701.

[22] P. Lodhi, O. Mishra, S. Jain shi_81@rediffmail. com, and V. Bajaj, 'StuA: An Intelligent Student Assistant', International Journal of Interactive Multimedia \& Artificial Intelligence, vol. 5, no. 2, pp. 17-25, Sep. 2018, doi: 10.9781/ijimai.2018.02.008.

[23] B. McMahan, 'An Automatic Dialog System for Student Advising', p. $14,2010$.

[24] A. S. Ghanem and H. Alobaidy, 'Data Mining for Intelligent Academic Advising from Noisy Dataset', in 2018 International Conference on Innovation and Intelligence for Informatics, Computing, and Technologies (3ICT), Nov. 2018, pp. 1-5, doi: 10.1109/3ICT.2018.8855790.

[25] Abdullah Al-Ghamdi, S. Al-Ghuribi, A. Fadel, F. Al-Aswadi, and T. AL-Ruhaili, 'An Expert System for Advising Postgraduate Students', (IJCSIT) International Journal of Computer Science and Information Technologies, vol. 3, no. 3, 2012.

[26] A. C. Rajput, 'Intelligent Counselor: An Intelligent Advisory System', IJSTE - International Journal of Science Technology \& Engineering, vol. 1, no. 9, p. 6, Mar. 2015.

[27] S. Ismail and S. Ismail, 'Methodology to Develop Neuro-Fuzzy Logic Expert Advising System in University', in 2018 IEEE Student Conference on Research and Development (SCOReD), Nov. 2018, pp. 1-6, doi: 10.1109/SCORED.2018.8711209.

[28] S. Lonn and S. D. Teasley, 'Student Explorer: A Tool for Supporting Academic Advising at Scale', in Proceedings of the First ACM Conference on Learning @ Scale Conference, New York, NY, USA, 2014, pp. 175-176, doi: 10.1145/2556325.2567867.
[29] M. Lamiaa, G. Oately, N. Khalifa, and W. Rabie, 'A Case based Reasoning System for Academic Advising in Egyptian Educational Institutions', in 2nd International Conference on Research in Science, Engineering and Technology (ICRSET'2014), March 21-22, 2014 Dubai (UAE), Mar. 2014, doi: 10.15242/IIE.E0314513.

[30] K. Ganeshan and X. Li, 'An intelligent student advising system using collaborative filtering', in 2015 IEEE Frontiers in Education Conference (FIE), Camino Real El Paso, El Paso, TX, USA, Oct. 2015, pp. 1-8, doi: 10.1109/FIE.2015.7344381.

[31] R. Shatnawi, Q. Althebyan, B. Ghalib, and M. Al-Maolegi, 'Building A Smart Academic Advising System Using Association Rule Mining, arXiv:1407.1807 [cs], Jul. 2014, Accessed: Mar. 18, 2019. [Online]. Available: http://arxiv.org/abs/1407.1807.

[32] K. Taha, 'Automatic Academic Advisor', presented at the 8th IEEE International Conference on Collaborative Computing: Networking, Applications and Worksharing, Dec. 2012, Accessed: Dec. 30, 2019. [Online]. https://eudl.eu/doi/10.4108/icst.collaboratecom.2012.250338.

[33] A. Mohamed, 'Interactive decision support for academic advising', Quality Assurance in Education: An International Perspective, vol. 24, no. 3, p. 349, Jul. 2016.

[34] A. Khamisa and N. Rabeia, 'An Intelligent Electronic Academic Advisor', International Journal of Computer Applications (0975 - 8887, vol. 181, no. 40, Feb. 2019, doi: 10.5120/ijca2019918419.

[35] S. Deorah, S. Sridharan, and S. Goel, 'SAES- expert system for advising academic major', in 2010 IEEE 2nd International Advance Computing Conference (IACC), Feb. 2010, pp. 331-336, doi: 10.1109/IADCC.2010.5422931.

[36] E. M. LATORRE-NAVARRO, 'An Intelligent Natural Language Conversational System For Academic Advising', Published by ProQuest LLC (2014)., May 2014.

[37] F. Gutiérrez, K. Seipp, X. Ochoa, K. Chiluiza, T. De Laet, and K. Verbert, 'LADA: A learning analytics dashboard for academic advising', Computers in Human Behavior, p. 105826, Dec. 2018, doi: 10.1016/j.chb.2018.12.004.

[38] R. F. Elcullada-Encarnacion, 'Academic advising system using data mining method for decision making support', in 2018 4th International Conference on Computer and Technology Applications (ICCTA), May 2018, pp. 29-34, doi: 10.1109/CATA.2018.8398651.

[39] W. Nwankwo, 'Interactive Advising with Bots: Improving Academic Excellence in Educational Establishments', American Journal of Operations Management and Information Systems, vol. 3, no. 1, p. 6, Mar. 2018, doi: 10.11648/j.ajomis.20180301.12.

[40] C. H. Chan, H. L. Lee, W. Kwan Lo, and A. K.-F. Lui, 'Developing a Chatbot for College Student Programme Advisement', 2018 International Symposium on Educational Technology (ISET), Educational Technology (ISET), 2018 International Symposium on, ISET, p. 52, 2018, doi: 10.1109/ISET.2018.00021.

[41] S. Plak, I. Cornelisz, M. Meeter, and C. van Klaveren, 'Early Warning Systems for More Effective Student Counseling in Higher Education Evidence from a Dutch Field Experiment', In Proceedings of the SREE Spring 2019 Conference, Washington, DC, USA, vol. 6, no. 9, p. 26, Dec. 2019.

[42] G. Engin et al., 'Rule-based Expert Systems for Supporting University Students', Procedia Computer Science, vol. 31, pp. 22-31, Jan. 2014, doi: 10.1016/j.procs.2014.05.241.

[43] EckrothJoshua and AndersonRyan, 'Tarot: a course advising system for the future', Journal of Computing Sciences in Colleges, vol. 34, no. 3, Jan. 2019, Accessed: Dec. 30, 2019. [Online]. Available: https://dl.acm.org/doi/abs/10.5555/3306465.3306481.

[44] C. C. Abalorio and M. dela Cerna, 'Course Evaluation Generator (Ceg): An Automated Academic Advising System with Optical Character Recognition', International Journal of Technology and Engineering Studies, vol. 4, no. 5, pp. 189-196, Oct. 2018, doi: 10.20469/ijtes.4.10003-5. 